\title{
PENGARUH KUALITAS KEHIDUPAN KERJA TERHADAP KOMITMEN ORGANISASI MELALUI KEPUASAN KERJA PADA PT. SEGAR MURNI UTAMA
}

\author{
Rara Ayu Silvia Dwisaputri Sudiq \\ Universitas Negeri Surabaya \\ rarasudiq@mhs.unesa.ac.id \\ Dewie Tri Wijayanti \\ Universitas Negeri Surabaya \\ dewiewijayati@unesa.ac.id
}

\begin{abstract}
The purpose of this research is analyzed about Organizational Commitment (OC) effected by Quality Work of Life $(Q W L)$ through Job Satisfaction (JS). Causality research using quantitative approach. The sampling technique using saturated samples by the sample size of 45 respondents at PT. Segar Murni Utama. This research used Structural Equation Model (SEM) with the assistance of smart PLS 3.0 software as the statistics analysis. The results of this research show that Quality Work of Life positive influence on Commitment Organizational, Quality Work of Life positive influence on Job Satisfaction. However, Job Satisfaction doesn't affect Commitment Organizational. So, Job Satisfaction was not become an intervening variety of Quality Work of Life on the Commitment Organizational.
\end{abstract}

Keywords: commitment organizational; job satisfaction; quality work of life.

\section{PENDAHULUAN}

Semakin ketat persaingan dalam dunia bisnis menghadapkan suatu organisasi/perusahaan dalam memenuhi kebutuhan publik yang memiliki daya saing yang efisien dan ketat. Dalam meningkatkan efisiensi tersebut tentu memerlukan pula sumber daya manusia berkualitas (Ace, 2017). Pada sumber daya menusia akan senantiasa melekat pada stiap organisasi sebagai salah satu fektor penentu akan peranan dan keberadaannya untuk memberikan kontribusi yang selaras dengan tujuan yang ingin perusahaan capai secara efektif \& efisien. Suatu organisasi/perusahaan dapat dikatakan baik, apabila telah mampu memahami kayawannya dengan baik dalam pencapaian tujuan organisasi secara objektif, dengan kepentingan menyediakan kebutuhan karyawanya. Hal tersebut dapat dicapai dalam kondisi apapun, apabila organisasi/perusahaan tersebut mampu menyesuaikan peerubahan dan perkembangan yang ada sesuai harapan, dengan selalu mengikuti alur menuju pencapaian tujuan organisasi yang telah disepakati sebelumnya (Wijayati, et al., 2018).

Permasalahan dari seorang karyawan akan menjadi hal yang penting karena pengaruh dalam pencapaian tujuan organisasi/perusahaan. Karena tersedianya karyawan yang berkualitas akan menjadi aset yang tidak ternilai bagi sebuah organisasi/perusahaan . Berkualitasnya SDM tentu memiliki karakteristik tersendiri, yang mana salah satunya terdapat komitmen karyawan pada sebuah organisasi. Komitmen organisasi yang tinggi seorang karyawan menjadikan karyawan tersebut akan mengerjakan bukan hanya job desciption yang sudah diwajibkannya, melainkan karyawan tersebut akan dengan suka rela mengerjakan hal-hal yang dapat digolongkannya sebagai usaha ekstra. Karena jika pada karyawan memiliki komitmen tinggi maka ia akan merasa memiliki organisasi tersebut (Jati, 2013).

Karyawan adalah elemen penting bagi perusahaan dalam operasional keseluruhan akan sumber daya yang dikelolanya. Dari hal tersebut tentu diperlukan bagi sebuah perusahaan dalam mengembangkan cara-cara terbaru dalam pengelolaan sumber dayanya sehingga upaya yang dilakukan dalam meningkatkan kemajuan perusahaan dapat dimanfaatkan dengan baik. Salah satunya dengan meningkatkan kualitas kehidupan kerja bagi para karyawannya (Maharani, 2018). Pada kualitas kehidupan kerja karyawan bagi para ilmuan maupun praktisi dipandang sebagai topik yang dianggap penting bagi sebuah organisasi/perusahaan dan senantiasa menarik untuk ditinjau lebih lanjut lagi. Kualitas kehidupan kerja dianggap dapat memengaruhi jalannya sebuah perusahaan secara menyeluruh dalam pencapaian tujuan. 
Rara Ayu Silvia Dwisaputri Sudiq \& Dewie Tri Wijayanti. Pengaruh Kualitas Kehidupan Kerja terhadap Komitmen Organisasi melalui Kepuasan Kerja pada PT. Segar Murni Utama

Hal tersebut menunjukkan kemampuan untuk meningkatkan kondisi maupun peran yang lebih dari karyawan dalam kualitas kehidupan kerja terhadap komitmennya di sebuah organisasi/perusahaan (Jati, 2013).

Menurut Ace (2017), pada perusahaan yang baik, perusahaan yang mampu menciptakan dan menjaga kepuasan kerja sehingga nantinya merangsang karyawan dalam bekerja sesuai dengan standar yang telah ditetapkan serta komitmen tinggi karyawan akan perusahaan tersebut. Dasarnya karyawan bersifat individual dalam menentukan tingkat kepuasan yang dirasakannya, di mana pada tiap individu memiliki tingkatan berbeda-beda yang sesuai dengan nilai yang telah diberlakukan dari individual karyawan tersebut. Bagi karyawan yang sudah merasa puas dari apa yang diperolehnya dari suatu organisasi/perusahaan maka karyawan mengupayakan usahanya melebihi dari apa yang perusahaan harapkan dengan meningkatkan komitmennya serta karyawan akan selalu berusaha mengevalusi untuk bekerja lebih baik dalam kinerjanya. Berkebalikan dengan hal tersebut jika pada karyawan dengan kepuasan kerja rendah, maka karyawan kedepannya merasa jika pekerjaannya merupakan hal yang membosankan dan menjenuhkan, yang pada akhirnya membuat karyawan mengerjakannya asal-asalan dan melakukannya tidak dengan sepenuh hati.

Maharani (2018) menyatakan bahwa pada kualitas kehidupan kerja dan lingkungan kerja memiliki pengaruh yang signifikan terhadap komitmen organisasi pada PT Barata Indonesia (Persero) Gresik. Berbeda dengan hasil penelitian dari Asharini, Hardyastuti, \& Irham (2018) yang menyatakan pada kualitas kehidupan kerja tidak berpengaruh terhadap komitmen organisasi. Penelitian yang dilakukan Novita (2017) pada guru SMP Negeri di seluruh kecamatan Teluknag, Tangerang dari analisis data dalam penelitiannya mrnyimpulkan bahwa kualitas kehidupan kerja memiliki pengaruh langsung terhadap kepuasan kerja. Akan tetapi berbeda dengan hasil penelitian Arifin (2012) yang menyatakan bahwa kualitas kehidupan kerja tidak berpengaruh terhadap kepuasan karywan pada CV. Duta Senan Jepara. Pada penelitian yang telah dilakukan oleh Nath Gangai \& Agrawal ( 2015) yang menyatakan dalam hasil penelitiannya menemukan tidak adanya korelasi yang signifikan dari kepuasan kerja dan komitmen organisasi karyawan pada karyawan EN Reality di India. Hal tersebut ditunjukkan dengan karyawan yang turut merasa memiliki oganisasi. Alasan karyawan yang berkomitmen pada organisasi hanya karena mereka membutuhkannya bukan karena kepuasan mereka. Namun penelitian tersebut berbeda dengan penelitian yang telah dilakukan oleh Ningkiswari \& Wulandari (2017) menyatakan bahwa dari hasil penelitian pada karyawan Rumah Sakit Undaan di Surabaya pada kepuasan kerja terhadap komitmen organisasi berpengaruh signifikan.

Bedasarkan hasil wawancara peneliti dengan bapak Handoko PT. Segar Murni Utama yang merupakan sebuah perusahaan dalam bidang air minum dalam kemasan (AMDK) dalam memproduksi air mineral dengan nama produk TRAS. Di awal tahun 2019 terdapat karyawan yang di lock out oleh perusahaan. Namun faktanya, para karyawan yang di lock out justru ingin kembali (komitmen) dan bekerja di perusahaan tersebut dengan berbagai alasan. Selain itu menurut hasil observasi pada penelitian di lapangan masih terdapat karyawan yang menerima gaji di bawah UMR Mojokerto meski tidak seluruhnya.

Penelitian ini bertujuan untuk mengkaji dan menganalisis pengaruh dari kualitas kehidupan kerja karyawan terhadap komitmen organsisasi melalui kepuasan kerja pada karyawan PT.Segar Murni Utama di Mojokerto.

\section{KAJIAN PUSTAKA DAN PENGEMBANGAN HIPOTESIS}

\section{Komitmen Organisasi}

Menurut (Yorulmaz \& Yucel, 2016) komitmen organisasi mengacu pada keterikatan psikologis yang dirasakan pekerja terhadap organisasi mereka. Komitmen organisasi sendiri berasal dari minat mereka (pekerja) akan pekerjaan mereka, kesetiaan mereka, dan keyakinan kuat mereka terhadap budaya dan nilai-nilai organisasi. Yang mana komitmen organisasi, mencerminkan penerimaan tujuan serta nilainilai organisasi dari pekerja, hal tersebut dapat dipandang dari sejauh mana pekerja melihat organisasi 
sebagai keluarga, serta dirinya sebagai anggota keluarga (organisasi) tersebut dan kesediaan dari pekerja untuk terus bekerja di organisasi tersebut.

Menurut Rejeki \& Wulansari (2015), loyalitas dan kesetiaan berkaitan dengan komitmen organisasi di mana dianggap sebagai tindakan perilaku dan ikatan antar individu dari para karyawan. Indikator komitmen organisasi pada penelitian ini mengacu pada penelitian menurut Rejeki \& Wulansari (2015) komitmen organsiasi terdiri dari keloyalan karyawan akan perusahaan, kesesuaian antara nilai pribadi dengan organisasi dari karyawan, rasa bangga dari karyawan akan perusahaan tempat ia bekerja, pekerjaan yang memberikan inspirasi pada karyawan, dan perhatian dari karyawan pada keberlangsungan perusahaan.

\section{Kualitas Kehidupan Kerja}

Menurut Bekti (2018), definisi dari kualitas kehidupan kerja ialah gambaran dari karyawan perihal kondisi kemakmuran individual karyawan baik fisik maupun mental dalam menjalankan pekerjaanya di sebuah organisasi/ perusahaan. Dengan menciptakan kualitas kehidupan kerja yang baik maka sebuah organisasi/ perusahaan harus mempunyai tujuan dalam iklim kerja yang terwujud sehingga nantinya dapat mendorong pekerjanya dalam motivasi karyawan dalam pekerjaannya supaya mengoptimalkan kinerjanya juga bertujuan agar pemenuhan kebutuhan para karyawan dengan mengoptimalkan persediaan akan sarana dan prasarana pada lingkungan kerja yang baik.

Menurut Chrisienty (2015), sejatinya kualitas kehidupan kerja ialah teknik dalam mengembangkan sebuag perusahaan yang dirancang dalam peningkatan akan fungsi dari organisasi/perusahaan yang memanusiakan pekerja dan lingkungan kerjanya, sehingga nantinya akan demokratis serta melibatkan langsung para karyawannya dalam keputusan yang diambil oleh organisasi/perusahaan tersebut. Jika pada karyawan yang mengutamakan keorganisasiannya dalam perusahaan, maka mereka akan dengan senang hati dan menjadi loyal dalam pekerjaan mereka. Maka dari itu, mereka akan senang jika harus terlibat dalam organisasi perusahaannya. Dalam penelitian ini, mengacu pada indikator menurut Chrisienty (2015) menyebutkan yaitu: pertumbuhan dan pengembangan, partisipasi, lingkungan fisik, pengawasan, gaji, inetgritas kerja.

\section{Kepuasan Kerja}

Menurut Bekti (2018), kepuasan hidup dari pribadi seorang karyawan merupakan komponen yang sangat penting dalam tingkat kepuasan kerja karyawan akan sebuah organisasi. Sehingga perlu untuk memperhatikan lebih lanjut upaya-upaya apa saja yang telah dilakukan suatu organisasi/perusahaan dalam mengembangkan serta pemeliharaan para karyawannya. Pada karyawan dengan tingkat kepuasan yang tinggi mereka akan mampu untuk berinteraksi dengan baik terhadap lingkungan kerja dalam bekerjanya nanti serta ia akan bekerja dengan semangat yang tinggi dan penuh rasa kesungguhan dalam mencapai tujuan organisasi/perusahaan tempat ia bekerja.

Menurut Changgriawan (2017), berdasarkan dari persepsi karyawan, kepuasan kerja merupakan perasaan positif yang terbentuk akan nilai individual dari para karyawan terhadap pekerjaan yang dilakukannya dalam sebaik apakah pekerjaan yang telah ia lakukan. Penelitian ini mengacu dari indikator kepuasan kerja menurut Changgriawan (2017) antara lain: kepuasan karyawan terhadap gaji/upah, kepuasan karyawan akan pekerjaan itu sendiri, kepuasan terhadap rekan kerja, puas akan kesempatan promosi yang diterima karyawan, kepuasan karyawan dari perlakuan pengawas (atasan).

\section{Hubungan antar Variabel}

Menurut Kaunang, Pio, \& Roring (2017) dalam penelitianya menyebutkan bahwa kualitas kehidupan kerja berpengaruh positif dan signifikan terhadap komitmen organisasional pada PT Hasjrat Abadi cabang Manado. Dimana peneliti tersebut berpendapat dengan meningkatnya kualitas kehidupan kerja akan meningkatkan komitmen organisasional secara signifikan. Hal tersebut juga didukung oleh penelitian dari Maharani, (2018) yang menyatakan bahwa adanya hubungan yang signifikan antara kualitas kehidupan kerja dengan komitmen organisasi. Namun hal tersebut berbeda dari penelitian Asharini, Hardyastuti, \& 
Rara Ayu Silvia Dwisaputri Sudiq \& Dewie Tri Wijayanti. Pengaruh Kualitas Kehidupan Kerja terhadap Komitmen Organisasi melalui Kepuasan Kerja pada PT. Segar Murni Utama

Irham, (2018) yang dijelaskan dalam hasil penelitiannya bahwa kualitas kehidupan kerja tidak berpengaruh terhadap komitmen organisasi.

H1: Kualitas kehidupan kerja berpengaruh signifikan positif terhadap komitmen organisasi pada karyawan PT. Segar Murni Utama.

Menurut Astitiani \& Surya (2016) dalam penelitiannya menunjukkan bahwa kualitas kehidupan kerja berpengaruh pada kepuasan kerja karyawan. Hal tersebut mengimplementasikan bahwa kualitas kehidupan kerja yang diterapkan perusahaan dapat meningkatkan kepuasan kerja karyawan. Sama halnya dengan penelitian yang telah dilakukan oleh Novita (2017) yang menyatakan bahwa pada kualitas kehidupan kerja berpengaruh langsung dan positif terhadap kepuasan kerja pegawai (guru). Namun berbeda dengan Negara, S, \& Dwipayana (2015) dari penelitiannya menunjukkan variabel kualitas kehidupan kerja tidak berpengaruh signifikan terhadap kepuasan kerja karyawan. Artinya bahwa kualitas kehidupan kerja ini secara langsung tidak mempengaruhi kepuasan kerja karyawan.

H2: Kualitas Kehidupan kerja berpengaruh signifikan positif terhadap kepuasan kerja pada karyawan PT. Segar Murni Utama.

Ningkiswari \& Wulandari (2017) yang menyatakan dalam hasil penelitiannya bahwa kepuasan kerja berpengaruh secara kuat terhadap komitmen karyawan. Maka dapat diartikan bahwa peningkatan kepuasan kerja cenderung dapat meningkatkan komitmen karyawan. Hal tersebut juga didukung oleh Hidayat (2018) yang menyatakan dari hasil penelitiannya menunjukkan adanya pengaruh signifikan dari kepuasan kerja pada komitmen organisasi. Kepuasan kerja mencerminkan perasaan karyawan terhadap pekerjaannya dan berkomitmen terhadap organisasi. Namun menurut Nath Gangai \& Agrawal ( 2015) dalam hasil penelitiannya menemukan tidak adanya korelasi yang signifikan antara kepuasan kerja dan komitmen organisasi.

H3: Kepuasan kerja berpengaruh signifikan positif terhadap komitmen organisasi pada karyawan PT. Segar Murni Utama.

Penelitian terdahulu yang dilakukan oleh Sudaryatun (2014) yang menghasilkan kepuasan kerja memediasi pengaruh tidak langsung dari kualitas kehidupan kerja terhadap komitmen organisasi pada pegawai Badan Pusat Statistik (BPS) di Provinsi D.I. Yogyakarta. Maka berdasarkan dari teori para ahli dan penelitian terdahulu dengan fenomena yang ada pada perusahaan, maka fokus penelitian ini adalah membuktikan variabel kualitas kehidupan kerja terhadap komitmen organisasi melalui kepuasan kerja. Hubungan antar variabel dalam hipotesis penelitian ini juga dapat dilihat pada gambar 1.

H4: Kualitas kehidupan kerja berpengaruh signifikan positif terhadap komitmen organisasi melalui kepuasan kerja pada karyawan PT. Segar Murni Utama.

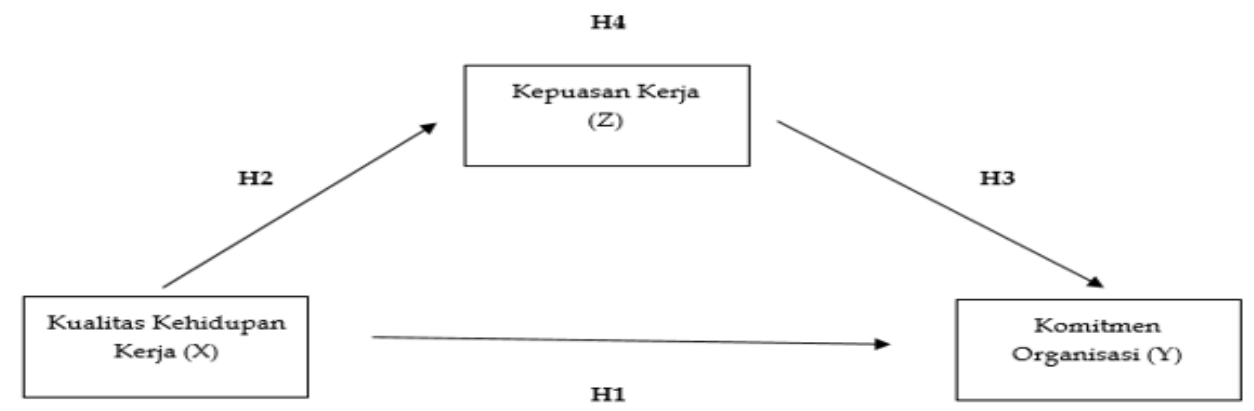

Gambar 1. KERANGKA KONSEPTUAL 


\section{METODE PENELITIAN}

Teknik dalam penelitian kuantitatif ini mengaplikasikan pendekatan yang dilakukan peneliti di PT. Segar Murni Utama di Mojokerto. Ukuran sampel dalam penelitian ini sebesar 45 responden yang juga mempergunakan teknik sampel jenuh. Dengan skala likert 1-5 dalam pengukurannya. Uji validitas dalam riset ini dinilai dari konstruk dengan melihat nilai AVE model yang dinyatakan baik apabila AVE dari masing-masing konstruk nilainya melebihi nilai 0,50 (Ghozali, 2014:40). Uji reliabilitas konstruk diukur dengan dua kriteria yakni composite reliability dan cronbach alpha dari blok indikator yang mengukur konstruk. Structural Equation Modelling (SEM) digunakan sebagai teknik dalam analisis data dengan menggunakan dukungan dari software Partial Least Square (PLS) versi 3.0.

\section{HASIL DAN PEMBAHASAN}

\section{Karakteristik responden}

Responden pada penelitian ini adalah seluruh karyawan PT. Segar murni utama di Kabupaten Mojokerto. Kuisioner disebarkan kepada responden pada tanggal 6 Januari 2020. Dari 45 kuisioner yang telah disebarkan semua kembali yaitu 45 kuisioner. Karakteristik responden selengkapnya dapat dilihat di tabel 1.

\section{KARAKTERISTIK RESPONDEN}

\begin{tabular}{llcc}
\hline & Keterangan & Frekuensi & \% \\
\hline Usia & 20-29 tahun & 13 & 28,9 \\
& 30-39 tahun & 23 & 51,1 \\
Jenis & $>40$ tahun & 9 & 20 \\
Kelamin & Laki-laki & 35 & 77,8 \\
Pendidikan & Perempuan & 10 & 22,2 \\
Terakhir & SLTP & 7 & 15,6 \\
& SLTA & 18 & 40 \\
& D3 & 10 & 22,2 \\
Masa Kerja & 0-5 tahun & 10 & 22,2 \\
& 6-10 tahun & 5 & 11,1 \\
Status & $>10$ tahun & 31 & 20 \\
& Sudah Menikah & 32 & 71,1 \\
Masa Kerja & Belum Menikah & 13 & 28,9 \\
& 0-5 tahun & 5 & 11,1 \\
& 6-10 tahun & 9 & 20 \\
& $>10$ tahun & 31 & 68,9 \\
Jabatan & Karyawan & 31 & 68,9 \\
& Supervisor & 6 & 13,3 \\
& Manajer & 8 & 17,8 \\
& Manajer & 3 & 5,0 \\
& Total & $\mathbf{4 5}$ & $\mathbf{1 0 0}$ \\
\hline \multirow{5}{*}{ Sumber: Data diolah } & &
\end{tabular}

Sumber: Data diolah (2020)

\section{Construct Reliability}

Nilai reabilitas penelitian ini dinilai baik pada hasil uji reabilitas dikarenakan telah memenuhi syarat dengan menunjukkan nilai composite reliability lebih besar dari 0,70 \& cronbach's alpha pada konstruk seluruhnya berada di atas 0,60 . 
Rara Ayu Silvia Dwisaputri Sudiq \& Dewie Tri Wijayanti. Pengaruh Kualitas Kehidupan Kerja terhadap Komitmen Organisasi melalui Kepuasan Kerja pada PT. Segar Murni Utama

\section{Analisis R-Square}

Dari output SmartPLS 3.0 yang menghasilkan nilai R-square yang ditunjukkan pada tabel2. Pada pengaruh dari kualitas kehidupan kerja terhadap komitmen organisasi menunjukan nilai $R$-square 0,184 . Sehingga menjelaskan bahwa pada variabel konstruk kepuasan kerja sebesar 18,4\%, sedangkan $81,6 \%$ merupakan variabel lain yang tidak tercantum dalam penelitian ini.

Tabel 2

\section{R-SQUARE MODEL}

\begin{tabular}{cc}
\hline Variabel & R-Square \\
\hline Kepuasan Kerja & 0,184 \\
Komitmen organisasi & 0,232 \\
\hline Sumber: Output SmartPLS 3.0, 2020
\end{tabular}

Tabel 2 menunjukkan efek kualitas kehidupan kerja terhadap komitmen organisasi karyawan yang memiliki nilai R-Square sebesar 0,232 di mana menunjukkan bahwa variabel konstruk komitmen organisasi karyawan sebesar $23,2 \%$, sedangkan pada variabel 76,8 lainnya yang tidak tercantum sebesar $76,8 \%$.

\section{Uji Kausalitas}

Inner model digunakan penelitian ini dalam menganalisa pengaruh dari antar konstruk serta nilai signikan pada path coefficient yang digambarkan tabel 3.

TABEL 3

HASIL PATH COEFFITIENTS

\begin{tabular}{lcccc}
\hline \multicolumn{1}{c}{ Hubungan antar Variabel } & Original Sampel & T-Statistics & Keterangan & Hasil Hipotesis \\
\hline $\begin{array}{l}\text { Kualitas Kehidupan Kerja } \rightarrow \\
\text { Komitmen Organisasi }\end{array}$ & 0,458 & 2,700 & $\begin{array}{c}\geq 1,96 \\
\text { (Signifikan) }\end{array}$ & Hipotesis Diterima \\
$\begin{array}{l}\geq 1,96 \\
\text { Kualitas Kehidupan Kerja } \rightarrow\end{array}$ & 0,429 & 3,480 & Hipotesis Diterima \\
$\begin{array}{l}\text { Kepuasan Kerja } \\
\begin{array}{l}\text { Kepuasan Kerja } \rightarrow \text { Komitmen } \\
\text { Organisasi }\end{array}\end{array}$ & 0,049 & 0,268 & $\begin{array}{c}\geq 1,96 \text { (Tidak } \\
\text { Signifikan) }\end{array}$ & Hipotesis Ditolak \\
$\begin{array}{l}\text { Kualitas Kehidupan Kerja } \rightarrow \\
\begin{array}{l}\text { Kepuasan Kerja } \rightarrow \text { Komitmen } \\
\text { Organisai }\end{array}\end{array}$ & $-0,061$ & 0,822 & $\begin{array}{c}\geq 1,96 \text { (Tidak } \\
\text { Signifikan) }\end{array}$ & Hipotesis Ditolak \\
\hline
\end{tabular}

Sumber: Output SmartPLS 3.0, 2020

Tabel 3 menunjukkan bahwa kualitas kehidupan kerja memiliki pengaruh terhadap komitmen organisasi. Hal ini dapat dibuktikan dari nilai t-statistics sebesar 2,700 yang lebih dari 1,96 dan dengan nilai koefisien sebesar 0,458. Sehingga H1 diterima. Kualitas kehidupan kerja memiliki pengaruh terhadap kepuasan kerja. Hal ini dapat dibuktikannya dengan nilai $t$-statistics yang sebesar 3,480 yang lebih dari 1,96 dan dengan nilai koefisien sebesar 0,429, sehingga H2 diterima. Kepuasan kerja tidak memiliki pengaruh terhadap komitmen organisasi. Hal tersebut dapat dibuktikan dari nilai $t$-statistics sebesar 0,268 yang lebih rendah dari 1,96 dan dengan nilai koefisien sebesar 0,049, sehingga menghasilkan H3 ditolak. Pengaruh tidak langsung menunjukkan nilai koefisien pengaruh kualitas kehidupan kerja terhadap komitmen organisasi melalui kepuasan kerja sebesar 0,822 lebih kecil dari 1,96, sehingga menghasilkan $\mathrm{H} 4$ ditolak.

\section{Pengaruh Kualitas Kehidupan Kerja terhadap Komitmen Organisasi}

Variabel kualitas kehidupan kerja memiliki pengaruh terhadap variabel komitmen organisasi. Riset menunjukkan bahwa variabel kualitas kehidupan kerja signifikansi terhadap komitmen organisasi. Hal tersebut karena hubungan antar karyawan dapat dikatakan sangat erat, mengingat mayoritas para karyawan bertetangga satu sama lain. Hal lain juga ditunjukkan dengan adanya pengadaan arisan bulanan antar para karyawan yang mana hal tersebut menunjukkan keakraban dan kekompakan antar karyawan untuk saling percaya dan berkumpul bersama. Berdasarkan wawancara dengan salah satu 
karyawan PT. Segar murni utama beliau adalah Bapak Huda karyawan pada bagian ekspedisi menyatakan bahwa beliau merasa memiliki rekan kerja yang membuatnya nyaman dalam melakukan pekerjaannya yang membuat beliau merasa betah dan ingin tetap berkomitmen dengan perusahaan.

Beliau mengatakan karyawan di perusahaan tersebut sudah seperti keluarganya sendiri. Para atasan karyawan di perusahaan tersebut juga sudah mampu mengembangkan kerjasama secara tim pada karyawan bawahannya. Di mana nantinya para karyawan akan memiliki perasaan nilai pribadi yang sama dengan nilai-nilai yang ada pada perusahaan. Maka akan dapat menciptakan komitmen yang tinggi dari para karyawan terhadap perusahaan. Mengingat para karyawan juga menghabiskan waktu sehari-hari bekerjanya dengan rekan kerja mereka, mulai dari mereka memulai pekerjaanya, berinteraksi, dan bekerja dalam tim yang kesemuanya merupakan komponen yang memengaruhi lingkungan karyawan dalam bekerja. Dari pernyataan tersebut maka dapat disimpulkan bahwa kualitas kehidupan kerja yang dirasakan karyawan dapat memengaruhi komitmen organisasi karyawan pada PT. Segar Murni Utama.

\section{Pengaruh Kualitas Kehidupan Kerja terhadap Kepuasan Kerja}

Variabel kualitas kehidupan kerja memiliki pengaruh terhadap variabel kepuasan kerja. Riset menunjukkan bahwa variabel kualitas kehidupan kerja signifikansi terhadap kepuasan kerja. Hal tersebut karena karyawan PT. Segar murni utama merasa di jika mereka saling mendukung serta dapat menjalin persahabatan dengan lingkungan kerja mereka. Dengan terjalinnya hubungan yang baik antar karyawan maka kepuasan kerja dari karyawan akan meningkat. Penelitian ini mendukung hasil dari penelitian ini telah dilakukan sebelumnya oleh Astitiani \& Surya (2016) penelitian yang dilaksanakan di Swastika Bungalows Sanur tersebut menggunakan metode sampel jenuh dalam data sampel yang sebesar 60 karyawan. Hasil dari penelitian tersebut menunjukkan bahwa kualitas kehidupan kerja berpengaruh pada kepuasan kerja karyawan.

Hasil wawancara dengan salah satu karyawan PT. Segar murni utama dengan ibu Leny selaku manajer pada bagian purchasing beliau menyatakan bahwa beliau merasa jalinan hubungan antara sesama karyawan bisa dikatakan sudah dalam jalinan persahabatan dengan saling mendukung di dalam lingkungan kerja mereka di mana para atasan juga memberikan kesempatan untuk berpartisipasi dalam pengambilan keputusannya. Beliau menyatakan bahwa ia memiliki keyakinan terhadap bawahannya akan kemampuannya dalam mengerjakan tugas yang diberikan oleh beliau.

Hal tersebut juga menunjukkan bahwa para atasan peduli terhadap kesejahteraan yang menimbulkan rasa kepuasan dari para karyawannya. Dari pernyataan tersebut maka penelitian dapat disimpulkan kualitas kehidupan kerja yang dirasakan karyawan dapat mempengaruhi kepuasan kerja karyawan pada PT. Segar Murni Utama.

\section{Pengaruh Kepuasan Kerja terhadap Komitmen Organisasi}

Variabel kepuasan kerja tidak memiliki pengaruh terhadap variabel komitmen organisasi. Riset menunjukkan bahwa variabel kepuasan kerja non signifikansi terhadap komitmen organisasi. Hal tersebut dikarenakan karyawan PT. Segar murni utama merasa kurang setuju dengan pernyataan tersebut karena menurut hasil observasi penelitian ini karyawan masih merasa kurang bangga akan pekerjaan yang ditekuninya. Hal tersebut dikhawatirkan karyawan nantinya tidak maksimal dalam menjalankan pekerjaannya dan mempengaruhi komitmen yang dimiliki para karyawan PT. Segar murni utama.

Hasil dari wawancara dengan salah satu karyawan pada bagian produksi bapak Irwan menuturkan bahwa beliau merasa kurang bangga dengan dengan pekerjaan yang ditekuninya bisa dikatakan karena beliau merasa ingin mengembangkan dan meningkatkan kemampuannya. Di mana ketika para karyawan menggunakan kemampuan mereka dalam pekerjaannya, maka mereka akan merasa bangga, percaya diri, dan mungkin bisa lebih berprestasi. Akan tetapi terkadang juga para karyawan juga merasa ingin mengembangkan dan meningkatkan kemampuannya. Sehingga dikhawatirkan nantinya para karyawan mereka akan mencari perusahaan yang mampu mengakomodasi keinginan mereka 
Rara Ayu Silvia Dwisaputri Sudiq \& Dewie Tri Wijayanti. Pengaruh Kualitas Kehidupan Kerja terhadap Komitmen Organisasi melalui Kepuasan Kerja pada PT. Segar Murni Utama

tersebut, yang akhirnya tingkat komitmen mereka pada perusahaan akan berkurang. Selain itu jawaban dari responden pada kepuasan kerja menunjukkan nilai terendah pada kepuasan kerja yaitu kepuasan terhadap pembayaran gaji atau upah gaji. Karyawan menerima gaji dibawah UMR kabupaten Mojokerto, hal tersebut tentu saja membuat para karyawan merasa kurang puas akan hal tersebut.

Pada hasil wawancara dengan Bapak Handoko selaku manajer HRD, memang ada karyawan yang gajinya masih di bawah UMR, namun sudah sebagian besar karyawan juga sudah mendapat gaji UMR, selain itu perusahaan juga memberikan tunjangan-tunjangan wajib, dan upah lembur bagi para karyawannya. Namun, masih ada karyawan yang merasakan kurangnya kepuasan akan gaji yang diterima oleh karyawan memungkinkan menurunnya tingkat komitmen organisasi dari para karyawan. Dari pernyataan tersebut peneliti dapat menyimpulkan bahwa pada kepuasan kerja tidak berpengaruh terhadap komitmen organisasi pada karyawan PT. Segar murni utama di Mojokerto.

\section{Pengaruh Kualitas Kehidupan Kerja terhadap Komitmen Organisasi melalui Kepuasan Kerja}

Pada variabel kepuasan kerja tidak berperan sebagai variabel intervening antara variabel kualitas kehidupan kerja karyawan terhadap variabel komitmen organisasi. Hal tersebut ditunjukkan dengan variabel kualitas kehidupan kerja karyawan memiliki pengaruh langsung pada komitmen organisasi, namun tidak berpengaruh secara tidak langsung jika melalui variabel kepuasan kerja sebagai variabel intervening. Ini menunjukkan bahwa dengan ada maupun tidaknya variabel kepuasan kerja, variabel kualitas kehidupan kerja tetap berpengruh terhadap variabel komitmen organisasi.

Hasil penelitian yang telah dilakukan di PT Segar murni utama menghasilkan pengaruh dari kualitas kehidupan kerja karyawan terhadap komitmen organisasi memiliki pengaruh signifikan karena pada dasarnya mayoritas para karyawan merasa nyaman dan mengenal dengan baik rekan kerjanya. Para karyawan lebih mementingkan hubungan antar rekan kerjanya dibandingkan dengan gaji yang didapatkannya. Mendapatkan gaji yang besar tentu penting, namun ternyata tidak cukup penting jika harus ditukarkan dengan hubungan yang baik antar karyawan dengan rekan kerja mereka yang sudah terjalin harmonis. Meskipun dengan gaji yang besar dapat memengaruhi komitmen organisasi dari para karyawan tetapi jika para karyawan merasakan hubungan yang kurang baik dengan rekan kerja, tentu pekerjaan tersebut akan terasa berat untuk dijalani. Sedangkan pada pengaruh kepuasan kerja terhadap komitmen tidak berpengaruh karena para karyawan lebih memilih untuk tetap bertahan di perusahaan tersebut meskipun karyawan merasa kurang bangga dengan pekerjaannnya dan bertahan dengan gajinya yang di bawah UMR. Hal tersebut juga karena karyawan merasa tidak ada pilihan lain, dengan sulitnya untuk mendapatkan pekerjaan yang baru dan peluang pekerjaan di perusahaan lain.

Berdasarkan dari pernyataan tersebut maka dapat disimpulkan bahwa pada variabel kepuasan kerja tidak dapat menjadi variabel yang mengintervening antara kualitas kehidupan kerja terhadap komitmen organisasi. Hal tersebut karena ada atau tidaknya variabel kepuasan kerja, kualitas kehidupan kerja tetap tidak berpengaruh terhadap komitmen organisasi karyawan PT. Segar Murni Utama, dan terdapat faktor-faktor lain yang lebih dibutuhkan oleh karyawan untuk lebih berkomitmen terhadap organisasi/perusahaan mereka.

Penelitian ini mendukung hasil penelitian yang telah dilakukan oleh Kholik (2014) yang menyatakan bahwa bahwa kepuasan kerja memediasi hubungan antara QWL dan komitmen organisasional namun pengaruh langsung lebih besar dari pada pengaruh tidak langsung.

\section{KESIMPULAN}

Penelitian ini menghasilkan kualitas kehidupan kerja berpengaruh terhadap komitmen organisasi, yang berarti semakin tinggi atau semakin rendah variabel kualitas kehidupan kerja akan memberikan pengaruh terhadap komitmen organisasi karyawan perusahaan. Selanjutnya pada pengaruh kualitas kehidupan kerja juga berpengaruh terhadap kepuasan kerja, yang berarti semakin tinggi atau semakin rendah variabel kualitas kehidupan kerja akan memberikan pengaruh terhadap kepuasan kerja pada 
karyawan perusahaan. Namun pada variabel kepuasan kerja tidak memiliki pengaruh terhadap komitmen organisasi yang mengindikasikan bahwa variabel kepuasan kerja tidak dapat mengintervening hubugan dari variabel kualitas kehidupan kerja terhadap komitmen organisasi pada PT. Segar Murni Utama di Mojokerto.

Berdasarkan hasil analisis penelitian sebaiknya perusahaan juga lebih memperhatikan jumlah gaji dan upah yang diberikan kepada karyawannya. Jika perusahaan ternyata tidak mampu untuk memberikan gaji serta upah yang lebih baik pada karyawannya, sebaiknya perusahaan secara terbuka memperlihatkan keuntungan yang diperoleh perusahaan pada karyawannya. Hal tersebut bertujuan agar para karyawan nantinya dapat memahami kemampuan perusahaan saat ini dalam pemberian gaji. Penelitian selanjutnya dapat melibatkan variabel lain seperti konflik peran, budaya kaizen, dan kompetensi.

\section{DAFTAR PUSTAKA}

Ace, A. (2017). Pengaruh Kualitas Kehidupan Kerja Dan Partisipasi Terhadap Kepuasan Kerja Perawat Rsud Bangkinang. JOM Fisip, 4(2), 1-8.

Arifin, N. (2012). Analisis Kualitas Kehidupan Kerja, Kinerja, dan Kepuasan Kerja pada CV. Duta Senenan Jepara. Jurnal Economia, 8(No 1), 11-21. https://doi.org/http://dx.doi.org/10.21831/economia.v8i1.797

Asharini, N. A., Hardyastuti, S., \& Irham, I. (2018). The Impact of Quality of Work Life and Job Satisfaction on Employee Performance of PT. Madubaru PG-PS Madukismo. Agro Ekonomi, 29(1), 146. https://doi.org/10.22146/ae.31491

Astitiani, N. L. P. S., \& Surya, I. B. K. (2016). Pengaruh Quality of Work Life Terhadap Motivasi Kerja Dan Kepuasan Kerja Karyawan. Matrik: Jurnal Manajemen, Strategi Bisnis Dan Kewirausahaan, 10(2), 156. https://doi.org/10.24843/matrik:jmbk.2016.v10.i02.p06

Bekti, R. R. (2018). Pengaruh Kualitas Kehidupan Kerja Terhadap Kepuasan Kerja Karyawan Rumah Sakit Ibu Dan Anak X Surabaya. Jurnal Administrasi Kesehatan Indonesia, 6(2), 156. https://doi.org/10.20473/jaki.v6i2.2018.156-163

Changgriawan, G. S. (2017). Pengaruh Kepuasan Kerja dan Motivasi Kerja Terhadap Kinerja Karyawan One Way Production. Agora, 5(3), 123-131.

Chrisienty, W. (2015). Pengaruh Quality of Work Life Terhadap Komitmen Organisasional Karyawan di Cv Sinar Plasindo. Agora, 3(2), 483-490.

Ghozali, I. (2014). Metode Alternatif Dengan Partial Least Squares (PLS) (4th ed.). Semarang: Universitas Diponegoro Semarang.

Hidayat, A. S. (2018). Pengaruh Kepuasan Kerja Terhadap Komitmen Organisasi dan Turnover Intention. Jurnal Manajemen Dan Pemasaran Jasa, 11(1), 51-66.

Irshad, E., \& Naz, S. (2011). AsiaNet. Journal of Humanities and Social Sciences, 37-61.

Jati, A. N. (2013). Kualitas Kehidupan Kerja dan Komitmen Organisasional: Hubungannya dengan Organization Citizenship Behavior. Kiat BISNIS, 5 No 2(2), 97-103.

Kaunang, F. F., Pio, R. J., \& Roring, M. (2017). Pengaruh Kualitas Kehidupan Kerja Terhadap Komitmen Organisasional pada PT. Hasjrat Abadi Manado. JURNAL ADMINISTRASI BISNIS UNSRAT, (c), 2-6. 
Rara Ayu Silvia Dwisaputri Sudiq \& Dewie Tri Wijayanti. Pengaruh Kualitas Kehidupan Kerja terhadap Komitmen Organisasi melalui Kepuasan Kerja pada PT. Segar Murni Utama

Koeshartono, D., \& Mersi. (2014). Pengaruh Kepuasan Kerja Terhadap Komitmen Organisasional. UAJY.

Lambert, E., \& Hogan, N. (2009). The Importance of job Satisfaction and Organizational Commitment in Shaping Turnover Intent: A Test of a Causal Model. Criminal Justice Review, 34(1), 96-118. https://doi.org/10.1177/0734016808324230

Lestari, A. W., \& Sambul, S. A. P. (2017). Pengaruh Kepuasan Kerja Terhadap Komitmen Organisasional PT. Bank Mandiri (PERSERO) Tbk. Area Manado. Jurnal Administrasi Bisnis, $1-6$.

Lestari, D. N., \& Dwityanto, A. (2015). Hubungan antara Kualitas Kehidupan Kerja dengan Komitmen Organisasi. (1).

Maharani, R. D. (2018). Jurnal Bisnis Dan Manajemen. Jurnal Bisnis Dan Manajemen, 2(31), 130.

Nath Gangai, K., \& Agrawal, R. (2015). Job satisfaction and organizational commitment: Is it important for employee performance. International Journal of Management and Business Research, 5(4), 269-278.

Negara, G. D., S, S. W. L. H., \& Dwipayana, I. K. M. (2015). Pengaruh Kualitas Kehidupan Kerja Terhadap Kepuasan Kerja Karyawan Melalui Motivasi Pada PT Bank Syariah Mandiri Kantor Cabang Jember ( The Effect Quality of Work Life on The Employee Job Satisfaction Through Motivation at PT Bank Syariah Mandiri Kantor C. (1996).

Ningkiswari, I. A., \& Wulandari, R. D. (2017). Pengaruh Kepuasan Kerja Terhadap Komitmen Karyawan Rumah Sakit Mata Undaan Surabaya. JAKI, 5, 162-167.

Novita, N. R. (2017). Pengaruh Kualitas Kehidupan Kerja Dan Keterlibatan Kerja Terhadap Kepuasan Kerja Guru Smp Negeri Se-Kecamatan Teluknaga Kabupaten Tangerang. Jurnal Manajemen Pendidikan, 8(1), 162. https://doi.org/10.21009/jmp.08115

Ovtaria, A., \& Soeling, P. D. (2014). Pengaruh Quality Of Work Life Terhadap Komitmen Keorganisasian Pegawai Tetap Kantor Pusat PT Garuda Indonesia (Persero) TBK. 1-24.

Rejeki, A. T., \& Wulansari, N. A. (2015). Pengaruh Keadilan Organisasional pada Komitmen Organisasional dengan Kepuasan Kerja sebagai Variabel Intervening. Management Analysis Journal, 4(4), 319-326.

Sudaryatun, W. (2014). Pengaruh Kualitas Kehidupan Kerja Dan Konflik Peran Terhadap Komitmen Organisasi Dengan Kepuasan Kerja Sebagai Variabel Intervening Di Bps Propinsi D.I. Yogyakarta. Jbti, V(1), 94-125.

Sugiyono. (2016). Metode Penelitian Kuantitatif, Kualitatif, dan $R \& D$. Bandung: ALFABETA.

Wijayati, D., Fazlurrahman, H., Hadi, H., \& Wijayati, D. (2018). The Mediating of Change Organization in the Effect of Strategic Leadership Style and Innovation The Mediating of Change Organization in the Effect of Strategic Leadership Style and Innovation. 8(4), 24-44. https://doi.org/10.6007/IJARBSS/v8-i4/3995

Yorulmaz, M., \& Yücel, G. (2016). Evaluation of Satisfaction and Organizational Commitment Shipyard and Horticultural Businesses Workers: A Study in Yalona. IIB International Refereed Academic Social Sciences Journal, 2016231975(1), 19-44. https://doi.org/10.17364/IIB.20162319755 